\title{
The Histomorphometry of Liver and Kidney of Hyperglycemic Albino Rats after Treatment with Tithonia diversifolia Leaf Extract
}

\author{
Rizki Fitrawan Yuneldi*, Tyas Rini Saraswati, Enny Yusuf Wachidah Yuniwarti \\ Department of Biology, Faculty of Science and Mathematics, Universitas Diponegoro, Indonesia \\ *Corresponding Author: fitrawan.rizki@gmail.com
}

Submitted: 2021-03-12. Revised: 2021-03-25. Accepted: 2021-07-25

\begin{abstract}
Tithonia diversifolia can be used as an antidiabetic, so it is necessary to study the safety of its use, especially the side effects on the liver and kidneys. This study aimed to determine the effect of using $T$. diversifolia leaf extract through histomorphometry observations of the liver and kidneys of hyperglycemic albino rats. The study design used a completely randomized design (CRD). This study used 20 male albino rats which were divided into five treatment groups, there were $\mathrm{T}_{0}$ (rat normal/control), $\mathrm{T}_{1}$ (hyperglycemic rat without $T$. diversifolia leaf extract), $\mathrm{T}_{2}$ (hyperglycemic rat administered with Glibenclamide $10 \mathrm{mg} / \mathrm{kg} \mathrm{BW}$ ), $\mathrm{T}_{3}$ (hyperglycemic rat administered with $T$. diversifolia leaf extract $150 \mathrm{mg} / \mathrm{kg} \mathrm{BW}$ ), $\mathrm{T}_{4}$ (hyperglycemic rat administered with $T$. diversifolia leaf extract 300 $\mathrm{mg} / \mathrm{kg} \mathrm{BW}$ ). Every treatment was repeated four times. The damage of hepatocyte and the glomerular cell was observed through histological structure observation by histomorphometry method using a photomicrography microscope (Olympus BX51). The results indicate that there were significant differences $(\mathrm{P}<0.05)$ in the variable of hepatocytes diameter and there was no significant different ( $\mathrm{P}>0.05)$ result on glomerular diameter, as well as kidney and liver weight. It was concluded that T. diversifolia leaf extract of 150 $\mathrm{mg} / \mathrm{kg} \mathrm{BW}$ and $300 \mathrm{mg} / \mathrm{kg} \mathrm{BW}$ are safe to be used as antidiabetic. It does not cause any side effects on the liver and kidneys of hyperglycemic albino rats. Thereby $T$. diversifolia leaf extract can be further tested as preparation of biopharmaca which can be used as herbal medicines for diabetics.
\end{abstract}

Key words: glomerular; hepatocyte; histomorphometry; hyperglycemia; Tithonia diversifolia

How to Cite: Yuneldi, R. F., Saraswati, T. R., \& Yuniwarti, E. Y. W. (2021). The Histomorphometry of Liver and Kidney of Hyperglycemic Albino Rats After Treatment with Tithonia diversifolia Leaf Extract. Biosaintifika: Journal of Biology \& Biology Education, 13(2), 135-141.

DOI: http://dx.doi.org/10.15294/biosaintifika.v13i2.29459

\section{INTRODUCTION}

Tithonia diversifolia is a herbal medicine native to Central America (Kato-Noguchi, 2020). In Indonesia, it is called kembang bulan, paitan, and insulin leaf (Ladeska et al., 2019). This plant can be used to treat diseases related to hyperglycemia (Chagas-Paula et al., 2012). Hyperglycemia is a condition of increasing blood glucose levels exceeding the normal limits (Mackey \& Whitaker, 2015). Hyperglycemic conditions can damage body organs such as the liver and kidneys (Pecoits-Filho et al., 2016). Liver is an organ that plays an important role in detoxification to convert toxic compounds into non-toxic compounds (Chiang, 2014). The kidneys function for the disposal of metabolic waste products by the body such as urea and creatinine (Renda, 2017), and elimination of toxic substances (Genuis et al., 2011).

The liver and kidney can be damaged during hyperglycemic conditions. Hyperglycemic conditions in albino rats can be characterized by the presence of blood glucose of more than $140 \mathrm{mg} / \mathrm{dL}$ (Mackey \& Whitaker, 2015). This condition causes glucose availability in cells to decrease, so the body will take the energy from other sources than carbohydrates such as lipids (Michael et al., 2013). Over a long period, hyperglycemia will increase lipid oxidation that is able to increase reactive oxygen species (ROS) compounds that can bind to hepatocyte and glomerular cell organic matter, resulting in damage of hepatocyte and glomerular cell (Barrett et al., 2010).

The damage of liver and kidney cells can be observed through histomorphometry. That is the measurement method by calculating the average diameter of hepatocytes and glomeruli using a photomicrography microscope (El-Gohary et al., 2011). Cell damage due to hyperglycemia can be overcome with Glibenclamide and antidiabetic compounds obtained from plants (Naveen \& Baskaran, 2018). Based on recommendations from the World Health Organization (WHO), many antidiabetic agents are obtained from plants (Kitukale \& Chandewar, 2014). Plant extracts are widely and effectively used in lowering blood glucose and decrease the side effects (Baroni et al., 2016). One of the medicinal plants that can be consumed as an antidiabetic treatment is $T$. diversifolia (Lawal et al., 2012).

Khaing et al. (2019) reported that $T$. diversifolia contains many components of active compounds, but 
only two main components have antidiabetic roles, namely flavonoids and sesquiterpenes. Flavonoids are antioxidants that can protect cells against damage caused by ROS. They can also inhibit pancreatic $\beta$ cell damage, whereas sesquiterpenes can inhibit damage to the kidney in hyperglycemic conditions (Marianne et al., 2011; Wang et al., 2010). Winarsi et al. (2012) reported that flavonoids can stimulate peripheral glucose utilization, by increasing the glycolysis and glycogenesis pathways. Flavonoids can simultaneously suppress glycogenolysis, gluconeogenesis pathways, and controlling blood glucose so that blood glucose levels decrease. Antioxidants in flavonoids also can donate their hydrogen atoms to bind to the free radicals, so they become stable compounds. Flavonoids can stimulate the regeneration of hepatocytes, and glomeruli cells in the kidney due to damage caused by hyperglycemia (Abdelmoaty et al., 2010).

The research on $T$. diversifolia has been conducted by Sari et al. (2018), that showed that administration of $150 \mathrm{mg} / \mathrm{kg} \mathrm{BW}$ and $300 \mathrm{mg} / \mathrm{kg}$ BW for $T$. diversifolia leaf extract 28 days can reduce blood glucose levels in hyperglycemic rats. According to Yuneldi et al. (2018), giving T. diversifolia 30 $\mathrm{mg} / \mathrm{BW} /$ day and $60 \mathrm{mg} / \mathrm{BW} /$ day for 28 days can improve rat liver function. Fakunle and Abatan (2007), reported that $T$. diversifolia leaf extract at a dose of $400 \mathrm{mg} / \mathrm{kg}$ BW for 14 days caused degeneration to necrosis in the liver and kidneys. A lot of research on $T$. diversifolia has been done. However, there has not been an analysis of side effects and the safety of the doses of 150 and 300 $\mathrm{mg} / \mathrm{kg} \mathrm{BW}$ on the liver and kidneys. Furthermore, it was necessary to further investigate the effect of $T$. diversifolia leaf extract on the histomorphometry of liver and kidney of hyperglycemic albino rats. This study aimed to examine the effect of $T$. diversifolia leaf extract through histomorphometry observations of the liver and kidneys of hyperglycemic albino rats. This study was expected to provide scientific information about the effect of $T$. diversifolia leaf extract on the liver and kidneys of hyperglycemic albino rats.

\section{METHODS}

\section{The preparation of $\boldsymbol{T}$. diversifolia leaf extract}

The fresh $T$. diversifolia leaves $(1000 \mathrm{~g})$ were collected and oven-dried at $50-60^{\circ} \mathrm{C}$ for $24-48$ hours. The dried leaves then were mashed using a blender. The powder of $100 \mathrm{~g}$ was soaked in $1 \mathrm{~L}$ of distilled water for 24 hours. The filtrate was evaporated using a rotary evaporator at $80^{\circ} \mathrm{C}$ resulted in a viscous paste.

\section{Animal study and treatment}

The animals used in this study were 20 male albino rats (2-3 months old) consisting of 4 normal male albino rats and 16 hyperglycemic male albino rats weighing approximately $200 \mathrm{~g}$. The albino rats were made hyperglycemic using alloxan at a dose of $150 \mathrm{mg} / \mathrm{kg}$ injecting by intraperitoneal for three days in a row (Yimam et al., 2014). Hyperglycemia in rats is a condition of rat blood glucose of more than 126 $\mathrm{mg} / \mathrm{dL}$ (Zubaidah et al., 2017). The animals were randomly divided into 5 treatment groups, there were $\mathrm{T}_{0}$ (rat normal/control), $\mathrm{T}_{1}$ (hyperglycemic rat without $T$. diversifolia leaf extract), $\mathrm{T}_{2}$ (hyperglycemic rat administered with $10 \mathrm{mg} / \mathrm{kg}$ BW of Glibenclamide), $\mathrm{T}_{3}$ (hyperglycemic rat administered with $150 \mathrm{mg} / \mathrm{kg}$ $\mathrm{BW}$ of $T$. diversifolia leaf extract), $\mathrm{T}_{4}$ (hyperglycemic rat administered with $300 \mathrm{mg} / \mathrm{kg}$ BW of $T$. diversifolia leaf extract) (Yuneldi et al., 2018; Sari et al., 2018). Each treatment was repeated 4 times. Tithonia diversifolia leaf extract with a dose of 150 and $300 \mathrm{mg} / \mathrm{kg}$ BW were made by dissolving 30 and $60 \mathrm{mg}$ of the extract into each $0.2 \mathrm{~mL}$ distilled water. The other treatment was Glibenclamide $10 \mathrm{mg} / \mathrm{kg}$ BW. All treatment was done orally for 28 days (Yuneldi et al., 2018). The Ethics Committee of the Faculty of Medicine, Universitas Diponegoro approved all procedures.

\section{The data collection and measurement}

The research variables observed were hepatocyte and glomerular diameter as well as liver and kidney weight. The liver and kidney tissues were stained using hematoxylin-eosin (HE). Hepatocyte histomorphometry measurements were determined by calculating the average diameter as measured by the longest and widest part of the hepatocyte cell. Glomerular histomorphometry measurement was also done by calculating the average diameter as measured by the longest and widest part of the glomerular. Observations were carried out using a photomicrography microscope (Olympus BX51) equipped with a computer (El-Gohary et al., 2011; Kotyk et al., 2016).

\section{Statistical analysis}

The data that had been obtained were analyzed by using analysis of variance (ANOVA) at 95\% confidence level by SPSS software version 15 (Yuneldi et al., 2021; Yuneldi et al., 2021). If there were significant different results, the analysis was continued using Duncan's test (Yuneldi et al., 2021; Yuneldi et al., 2021). 


\section{RESULTS AND DISCUSSION}

The results on the average diameter of hepatocytes showed significantly different results $(\mathrm{P}<0.05)$, but the glomerular diameter of hyperglycemic albino rats treated with $T$. diversifolia leaf extract after 28 days were not significantly different $(\mathrm{P}<0.05)$ between treatments (Table 1). The effect of $T$. diversifolia leaf extract on the average hepatocyte diameter of hyperglycemic albino rats showed significantly different results $(\mathrm{P}<0.05)$. The results of the advanced test analysis using the Duncan's test showed that there was a significant difference between $T_{1}$ and all treatments, but no significant difference between $T_{0}, T_{2}, T_{3}$, and $T_{4}$ (Table 1 ).

Table 1. Average hepatocyte and glomerular diameter of hyperglycemic albino rats after treatment of $T$. diversifolia leaf extract.

\begin{tabular}{lccccc}
\hline \multirow{2}{*}{ Variable } & \multicolumn{5}{c}{ Average \pm SD, Treatment } \\
\cline { 2 - 6 } & $\mathrm{T}_{0}$ & $\mathrm{~T}_{1}$ & $\mathrm{~T}_{2}$ & $\mathrm{~T}_{3}$ & $\mathrm{~T}_{4}$ \\
\hline Hepatocyte Diameter $(\mu \mathrm{m})$ & $19.46^{\mathrm{b}} \pm 1.00$ & $22.75^{\mathrm{a}} \pm 2.51$ & $20.02^{\mathrm{b}} \pm 0.54$ & $19.31^{\mathrm{b}} \pm 0.85$ & $18.27^{\mathrm{b}} \pm 0.38$ \\
Glomerular Diameter $(\mu \mathrm{m})$ & $92.00^{\mathrm{a}} \pm 3.47$ & $93.24^{\mathrm{a}} \pm 2.77$ & $93.30^{\mathrm{a}} \pm 2.39$ & $92.49^{\mathrm{a}} \pm 8.87$ & $94.94^{\mathrm{a}} \pm 6.60$ \\
\hline \multicolumn{2}{c}{${ }^{\mathrm{a}-\mathrm{b}}$ Different superscripts in the same row indicate significant differences $(\mathrm{P}<0.05)}$.
\end{tabular}

The significant different results of $T_{1}$ hepatocyte diameter $(22.75 \mu \mathrm{m})$ was due to an increase in hepatocyte diameter. For the $\mathrm{T}_{0}$, the average diameter of the hepatocyte was situated in the normal range. Rosioru et al. (2012) reported that the normal hepatocyte cell diameter in albino rats ranges from 17.01-21.93 $\mu \mathrm{m}$. The hepatocyte diameter of $\mathrm{T}_{1}$ was increased by $3.29 \mu \mathrm{m}$ as compared to $\mathrm{T}_{0}$. The increase in hepatocyte cell diameter was caused by swelling of the cytoplasm in the form of hydropic degeneration (Figure 1b).

Histologically, there was a swelling of cells in the $T_{1}$ in the form of hydropic degeneration that was characterized by unevenly eosin-stained cytoplasm due to water entering the cytoplasm. Hastuti (2006) reported that swelled cells in the form of hydropic degeneration will make the cytoplasm cannot be evenly stained by eosin because it is accumulated by water.
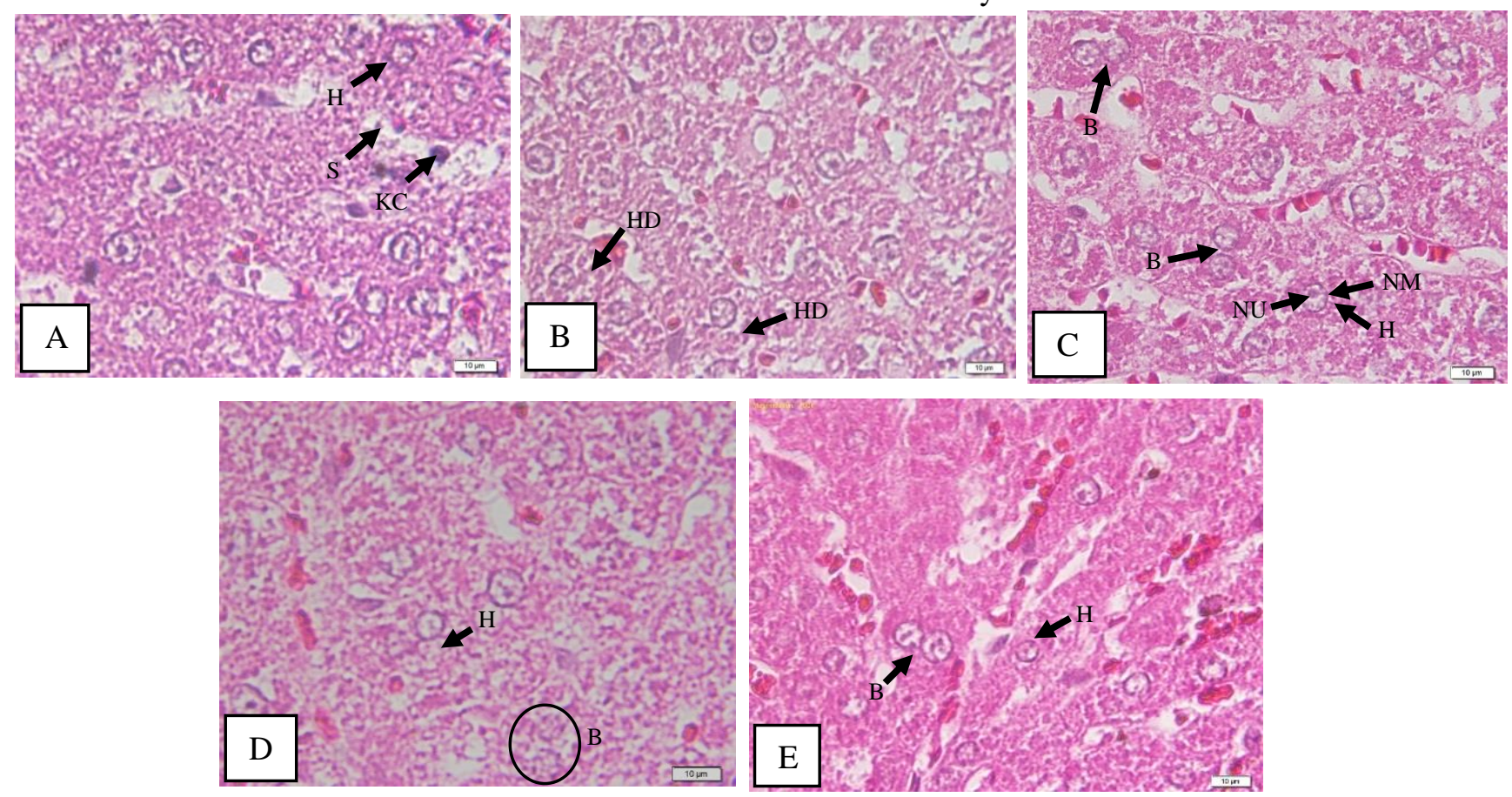

Figure 1. Liver histological structure of albino rats (Rattus norvegicus). A) $\mathrm{T}_{0}$, B) $\mathrm{T}_{1}$, C) $\mathrm{T}_{2}$, D) $\mathrm{T}_{3}$ and E) $\mathrm{T}_{4}$. 1000x magnification. Description: hematoxylin-eosin. H: Hepatocytes, S: Sinusoid, KC: Kupffer Cell, HD: Hydropic Degeneration, B: Binucleated Cell, NM: Nucleus Membrane, and NU: Nucleolus. 
Changes in hepatocyte structure in the form of hydropic degeneration are caused by ROS which was resulted from excessive lipid oxidation (Barrett et al., 2010). The mechanism of hepatocyte cells damaged by ROS starts from alloxan which damages pancreatic $\beta$ cells, then inhibits insulin secretion into the blood, so that glucose in the blood increases beyond a normal level which results in hyperglycemic conditions (Rohilla \& Ali, 2012). A hyperglycemic condition in albino rats causes glucose supply to the cells in a small amount so that the availability of glucose in cells decreases. The reduced availability of glucose in cells makes the body take the energy from other sources than carbohydrates, such as lipids (Michael et al., 2013). Hyperglycemic conditions over a long period will increase lipid oxidation and can produce excessive compounds of ROS that bind to hepatocyte cell organic matter, resulting in hepatocyte cell swelling (Barrett et al., 2010).

The average diameter of hepatocytes for $T_{1}$ was significantly different from $\mathrm{T}_{3}$ and $\mathrm{T}_{4}$. The treatment of $T_{3}$ and $T_{4}$ can regenerate cells and the diameter can return to be normal (Table 1 and Figure 1). The structure of hepatocytes in hyperglycemic albino rats damaged can be repaired by giving $T$. diversifolia leaf extract which contained flavonoid. Flavonoids are antioxidants that can stimulate the regeneration of hepatocytes quickly (Biswas et al., 2011). The content of flavonoids can also stimulate insulin secretion, regeneration of pancreatic $\beta$ cells, and regeneration of hepatocytes (Dheer \& Bhatnagar, 2010). Increased secretion of insulin will cause the increase of glucose oxidation that produces more energy so that it can be used for hepatocyte cell regeneration (Barrett et al., 2010).

The average diameter of glomeruli of hyperglycemic albino rats showed results that were not significantly different $(\mathrm{P}>0.05)$ (Table 1$)$. It happened because kidney glomerular diameter was still in the normal range and no glomerular damage occurred (Figure 2). These results are in accordance with Selmanoglu et al. (2012), that the normal glomerular diameter ranges from $76.0976 \mu \mathrm{m}$ to $92.3549 \mu \mathrm{m}$. This statement is supported by Kotyk et al. (2016), that the normal glomerular diameter are $81.79 \mu \mathrm{m}, 87.63 \mu \mathrm{m}$, and $97.40 \mu \mathrm{m}$. The administration of $T$. diversifolia leaf extract containing sesquiterpene compounds which can inhibit the damage to the kidney under hyperglycemic conditions and also inhibit glomerulonephritis. Wang et al. (2010) reported that sesquiterpene compounds in $T$. diversifolia can inhibit kidney damage in hyperglycemic conditions. Sesquiterpene compounds can also inhibit glomerulonephritis, as well as mesangial and podocyte cells damage (Sanchez-Niño et al., 2013).

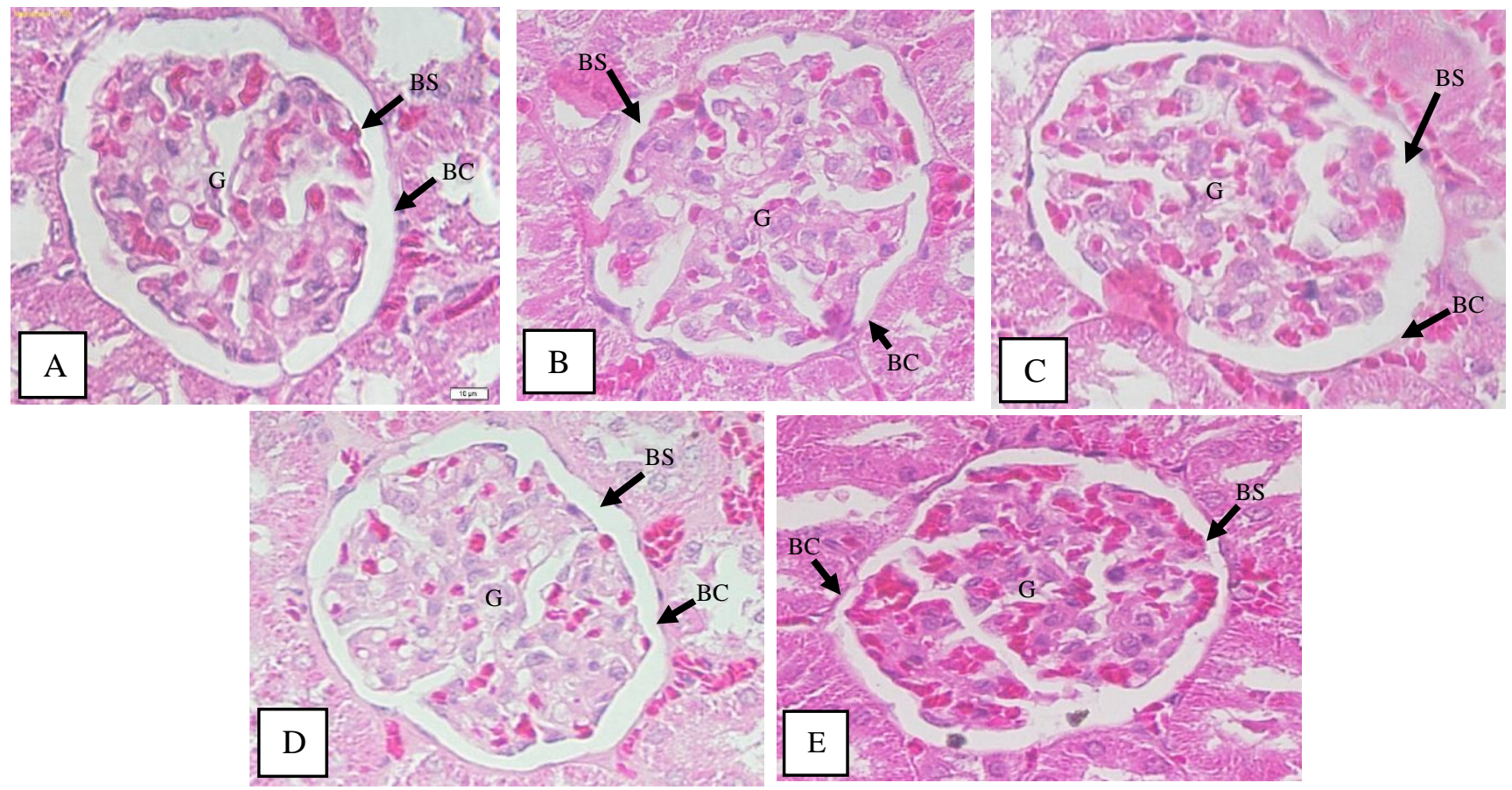

Figure 2. Kidney histological structure of albino rats (Rattus norvegicus). A) $\mathrm{T}_{0}$, B) $T_{1}$, C) $T_{2}$, D) $T_{3}$, E) $T_{4}$. 1000x magnification. Description: hematoxylin-eosin. G: Glomerular, BS: Bowman Space, and BC: Bowman Capsule. 
The effect of the administration of $T$. diversifolia leaf extract to the liver weight of hyperglycemic albino rats using ANOVA showed that the results were not significantly different $(\mathrm{P}>0.05)$ between treatments (Table 2). The results that were not significantly different showed that the liver structure was still in normal condition. Liver weight can be influenced by hepatocyte diameter. The increase in hepatocyte cell diameter has not been able to influence liver weight because it is in the form of hydropic degeneration which is still reversible, so that hepatocyte cells can regenerate (Kumar et al., 2018).

The increase in hepatocyte cell diameter was considered to have not affected overall hepatocyte cells so that there was no significant difference in liver weight. Increased liver weight is usually caused by fatty liver, as a result of necrosis (Niendya et al., 2011). Giving alloxan in treatment $T_{1}$ has not caused fatty liver, so there was no significant difference in liver weight. Fatty liver is an excessive lipid accumulation in the liver exceeding 5\% of liver weight (Green \& Hodson, 2014). The mechanism for the fatty hepatocyte cells begins with a hyperglycemic condition. Over a long period, hyperglycemic will increase lipid oxidation. Increased lipid oxidation can produce more excessive ROS compounds, resulting in an imbalance between the antioxidants and free radicals produced. This imbalance causes ROS to bind to hepatocyte cell organic matter, resulting in damage characterized by the presence of fatty cells in hepatocytes (Pratiwi et al., 2016).

Table 2. Average liver and kidney weight of hyperglycemic albino rats after treatment $T$. diversifolia leaf extract

\begin{tabular}{lccccc}
\hline \multirow{2}{*}{ Variable } & \multicolumn{5}{c}{ Average \pm SD, Treatment } \\
\cline { 2 - 6 } & $\mathrm{T}_{0}$ & $\mathrm{~T}_{1}$ & $\mathrm{~T}_{2}$ & $\mathrm{~T}_{3}$ & $\mathrm{~T}_{4}$ \\
\hline Liver Weight $(\mathrm{g})$ & $9.76^{\mathrm{a}} \pm 0.39$ & $10.97^{\mathrm{a}} \pm 0.60$ & $9.48^{\mathrm{a}} \pm 0.55$ & $10.06^{\mathrm{a}} \pm 1.06$ & $9.68^{\mathrm{a}} \pm 0.68$ \\
Kidney Weight $(\mathrm{g})$ & $1.71^{\mathrm{a}} \pm 0.13$ & $1.90^{\mathrm{a}} \pm 0.14$ & $1.55^{\mathrm{a}} \pm 0.18$ & $1.81^{\mathrm{a}} \pm 0.19$ & $1.83^{\mathrm{a}} \pm 0.13$ \\
\hline${ }^{\mathrm{a}-\mathrm{b}}$ Different superscripts in the same row indicate significant differences $(\mathrm{P}<0.05)$.
\end{tabular}

The effect of the administration of T. diversifolia leaf extract to the kidney weight of hyperglycemic albino rats showed results that were not significantly different $(\mathrm{P}>0.05)$ (Table 2). The average result of kidney weight was not significantly different because the kidney's structure was still in normal condition. Kidney weight can be affected by glomerular diameter. According to Nyengaard \& Bendtsen (1992), there is a correlation between the number and diameter of glomeruli and kidney weight. The results of glomerular diameter measurements were in the normal range and necrosis has not occurred, so the kidney weight in albino rats is also normal. Craig et al. (2015) reported kidney weight correlation with kidney histopathology. According to Rasch \& Dørup (1997), diabetic rats can increase kidney weight by 53 - 93\%. Another factor that is considered to cause changes in the kidney structure is the influence of toxic metabolic activities of chemical compounds (Craig et al., 2015).

Based on this study, $T$. diversifolia leaf extract of $150 \mathrm{mg} / \mathrm{kg} \mathrm{BW}$ and $300 \mathrm{mg} / \mathrm{kg} \mathrm{BW}$ are safe to be used as antidiabetic and does not cause side effects on the liver and kidneys of hyperglycemic albino rats. Therefore $T$. diversifolia leaf extract can be further tested as preparation of biopharmaca which can be expected as herbal medicines for diabetics.

\section{CONCLUSION}

Based on this research, it was concluded that $T$. diversifolia leaf extract of $150 \mathrm{mg} / \mathrm{kg} \mathrm{BW}$ and 300 $\mathrm{mg} / \mathrm{kg} \mathrm{BW}$ are safe to be used as antidiabetic. It does not cause any side effects on the liver and kidneys of hyperglycemic albino rats.

\section{REFERENCES}

Abdelmoaty, M. A., Ibrahim, M. A., Ahmed, N. S., \& Abdelaziz, M. A. (2010). Confirmatory studies on the antioxidant and antidiabetic effect of quercetin in rats. Indian Journal of Clinical Biochemistry, 25(2), 188-192.

Baroni, S., Rocha, B. A. D., Melo, J. O., Comar, J. F., Caparroz-Assef, S. M., \& Bersani-Amado, C. A. (2016). Hydroethanolic extract of Smallanthus sonchifolius leaves improves hyperglycemia of streptozotocin induced neonatal diabetic rats. Asian Pacific Journal of Tropical Medicine, 9(5), 432-436.

Barrett, K. E., Brooks, H. L., Boitano, S., \& Barman, S. M. (2010). Ganong's review of medical physiology. In McGraw-Hill.

Biswas, M., Kar, B., Bhattacharya, S., Kumar, R. B. S., Ghosh, A. K., \& Haldar, P. K. (2011). Antihyperglycemic activity and antioxidant role of Terminalia arjuna leaf in streptozotocin-induced 
diabetic rats. Pharmaceutical Biology, 49(4), 335340.

Chagas-Paula, D. A., Oliveira, R. B., Rocha, B. A., \& Costa, F. B. D. (2012). Ethnobotany, chemistry, and biological activities of the genus Tithonia (Asteraceae). Chemistry and Biodiversity, 9(2), 210-235.

Chiang, J. (2014). Liver physiology: Metabolism and detoxification. Pathobiology of Human Disease. Elsevier: San Diego, 1770-1782.

Craig, E. A., Yan, Z., \& Zhao, Q. J. (2015). The relationship between chemical-induced kidney weight increases and kidney histopathology in rats. Journal of Applied Toxicology, 35(7), 729736.

Dheer, R., \& Bhatnagar, P. (2010). A study of the antidiabetic activity of Barleria prionitis Linn. Indian Journal of Pharmacology, 42(2), 70-73.

El-Gohary, Z. M. A., Souad, A. K., Fahmy, A. M. E. S., \& Tag, Y. M. (2011). Comparative studies on the renal structural aspects of the mammalian species inhabiting different habitats. Journal of American Science, 7, 556-565.

Fakunle, J. O., \& Abatan, M. O. (2007). The toxicological effects of aqueous leaf extract of Tithonia diversifolia Gray in rats. Journal of Animal and Veterinary Advances, 6(10), 12231226.

Genuis, S. J., Birkholz, D., Rodushkin, I., \& Beesoon, S. (2011). Blood, urine, and sweat (BUS) study: Monitoring and elimination of bioaccumulated toxic elements. Archives of Environmental Contamination and Toxicology, 61(2), 344-357.

Green, C. J., \& Hodson, L. (2014). The influence of dietary fat on liver fat accumulation. Nutrients, 6(11), 5018-5033.

Hastuti, U. S. (2006). Pengaruh berbagai dosis citrinin terhadap kerusakan struktur hepatosit mencit (Mus musculus) pada tiga zona lobulus hepar. Jurnal Kedokteran Brawijaya, 22(3), 121126.

Kato-Noguchi, H. (2020). Involvement of allelopathy in the invasive potential of Tithonia diversifolia. Plants, 9(6), 1-9.

Khaing, Y. Y., Moe, M. M., Oo, S. S. (2019). Morphological, microscopical characters and phytochemical tests of Tithonia diversifolia (Hemsl.) A. Grays. Myanmar Korea Conference Research Journal, 3(3), 1148-1155.

Kitukale, M. D., \& Chandewar, A. V. (2014). An overview on some recent herbs having antidiabetic potential. Research Journal of Pharmaceutical Biological and Chemical Sciences, 5(6), 190-196.

Kotyk, T., Ashour, A. S., Chakraborty, S., Dey, N., Ashour, A. S., Tavares, J. M. R. S., \& BalasTimar, D. (2016). Measurement of glomerulus diameter and Bowman's space width of renal albino rats. Computer Methods and Programs in Biomedicine, 126, 143-153.

Kumar, V., Abbas, A. K., and Aster, J. C. (2018). Robbins and cotran, pathologic basis of a disease, 10th ed, chapter 19 - Female genital tract and the breast. In Elsevier Saunders.

Ladeska, V., Dewanti, E., \& Sari, D. I. (2019). Pharmacognostical studies and determination of total flavonoids of paitan (Tithonia diversifolia (Hemsl.) A. Gray. Pharmacognosy Journal, 11(6), 1256-1261.

Lawal, O. A., Kasali, A. A., Opoku, A. R., \& Oyedeji, A. O. (2012). Volatile constituents of the flowers, leaves, stems and roots of Tithonia diversifolia (Hemsely) A. Gray. Journal of Essential Oil-Bearing Plants, 15(5), 816-821.

Mackey, P. A., \& Whitaker, M. D. (2015). Diabetes mellitus and hyperglycemia management in the hospitalized patient. Journal for Nurse Practitioners, 11(5), 531-537.

Marianne, M., Yuandani, Y., \& Rosnani, R. (2011). Antidiabetic activity from ethanol extract of kluwih's leaf (Artocarpus camansi). Jurnal Natural, 11(2), 64-68.

Michael, L., Allan, M., \& Alisa, P. (2013). Marks' basic medical biochemistry: A clinical approach. In Basic medical biochemistry.

Naveen, J., \& Baskaran, V. (2018). Antidiabetic plant-derived nutraceuticals: A critical review. European journal of nutrition, 57(4), 1275-1299.

Niendya, A., Djaelani, M. A., \& Suprihatin, T. (2011). Rasio bobot hepar-tubuh mencit (Mus musculus L.) setelah pemberian diazepam, formalin, dan minuman beralkohol. Buletin Anatomi dan Fisiologi, 19(1), 16-27.

Nyengaard, J. R., \& Bendtsen, T. F. (1992). Glomerular number and size in relation to age, kidney weight, and body surface in normal man. The Anatomical Record, 232(2), 194-201.

Pecoits-Filho, R., Abensur, H., Betônico, C. C. R., MacHado, A. D., Parente, E. B., Queiroz, M., Salles, J. E. N., Titan, S., \& Vencio, S. (2016). Interactions between kidney disease and diabetes: Dangerous liaisons. Diabetology and Metabolic Syndrome, 8(1), 1-21.

Pratiwi, H., Winarso, D., \& Handoyo, N. (2016). Kadar low density lipoprotein dan gambaran histopatologi hepar pada tikus putih model diabetes melitus tipe 1 dengan pemberian ekstrak etanol Curcuma. Jurnal Ilmu dan Teknologi Hasil Ternak, 11(1), 1-7.

Rasch, R., \& Dørup, J. (1997). Quantitative morphology of the rat kidney during diabetes 
mellitus and insulin treatment. Diabetologia, 40(7), 802-809.

Renda, R. (2017). Can salivary creatinine and urea levels be used to diagnose chronic kidney disease in children as accurately as serum creatinine and urea levels? A case-control study. Renal Failure, 39(1), 452-457.

Rohilla, A., \& Ali, S. (2012). Alloxan induced diabetes: Mechanisms and effects. International Journal of Research in Pharmaceutical and Biomedical Science, 3(2), 819-823.

Rosioru, C., Talu, S., Talu, M., Giovanzana, S., \& Craciun, C. (2012). Morphometric assessments for the healthy rat hepatocytes. Annals of the Romanian Society for Cell Biology, 17(1), 74-79.

Sanchez-Niño, M. D., Sanz, A. B., Ruiz-Andres, O., Poveda, J., Izquierdo, M. C., Selgas, R., Egido, J., \& Ortiz, A. (2013). MIF, CD74 and other partners in kidney disease: Tales of a promiscuous couple. Cytokine and Growth Factor Reviews, 24(1), 2340.

Sari, A. R., Saraswati, T. R., \& Yuniwarti, E. Y. W. (2018). Antihyperglycemic activity of aqueous extract of insulin leaves (Tithonia diversifolia) on hyperglycemic rats (Rattus norvegicus). Biosaintifika: Journal of Biology \& Biology Education, 10(3), 636-641.

Selmanoglu, G., Karacaoglu, E., Kilic, A., Kockaya, E. A., \& Turan, A. M. (2012). Toxicity of food contaminant furan on liver and kidney of growing male rats. Environmental Toxicology, 27(10), 613-622.

Wang, W. J., Wu, F., Qian, Y., Cheng, L. F., Shao, X. T., Tong, X. M., \& Li, H. (2010). Inhibition of inflammatory factors by parthenolide in human renal mesangial cells under hyperglycemic condition. African Journal of Biotechnology, 9(23), 3458-3463.

Winarsi, H., Sasongko, N. D., Purwanto, A., \& Nuraeni, I. (2012). In vitro antioxidant activity of the stem and leaves Amomum cardamomum extracts. In: Proceedings of International
Conference on Medicinal Plants. Purwokerto, 1113 Oct 2012.

Yimam, M., Zhao, J., Corneliusen, B., Pantier, M., Brownell, L., \& Jia, Q. (2014). Blood glucose lowering activity of aloe based composition, UP780, in alloxan induced insulin dependent mouse diabetes model. Diabetology and Metabolic Syndrome, 6(1), 1-8.

Yuneldi, R. F., Airin, C. M., Saragih, H. T., \& Astuti, P. (2021). Application of natural aromatase blocker towards the level of testosterone in rooster Layer [Gallus gallus gallus (Linn., 1758)]. Key Engineering Materials, 884, 251-255.

Yuneldi, R. F., Airin, C. M., Saragih, H. T., \& Astuti, P. (2021). Efficiency of testosterone administration on the performance of day old chick (DOC) Layer: Cockscomb size, T3/T4 ratio, and histopathological description of bursa fabricius. Advances in Biological Sciences Research, 12, 35-39.

Yuneldi, R. F., Airin, C. M., Saragih, H. T. S. S. G., \& Astuti, P. (2021). Profile of thyroid hormone in male Layer chickens given by testosterone. IOP Conference Series: Earth and Environmental Science, 686, 012028.

Yuneldi, R. F., Astuti, P., Saragih, H. T. S., \& Airin, C. M. (2021). Anadara granosa shell powder improves the metabolism, testosterone level, and sound frequency of Pelung chickens. Veterinary World, 14(6), 1564-1571.

Yuneldi, R. F., Saraswati, T. R., \& Yuniwarti, E. Y. W. (2018). Profile of SGPT and SGOT on male rats (Rattus norvegicus) hyperglycemic after giving insulin leaf extract (Tithonia diversifolia). Biosaintifika: Journal of Biology \& Biology Education, 10(3), 519-525.

Zubaidah, E., Putri, W. D. R., Puspitasari, T., Kalsum, U., \& Dianawati, D. (2017). The effectiveness of various Salacca Vinegars as therapeutic agent for management of hyperglycemia and dyslipidemia on diabetic rats. International Journal of Food Science, 2017, 1-7. 